\title{
Glacial facies associations in a Neoproterozoic back-arc setting, Zavkhan Basin, western Mongolia
}

\author{
J. F. LINDSAY*, M. D. BRASIER †, G. SHIELDS $\ddagger$, V. V. KHOMENTOVSKY§
}

\& Y. A. BAT-IREEDUIII

* Australian Geological Survey Organisation, P. O. Box 378, Canberra, ACT 2601, Australia

† Earth Sciences Department, Parks Road, Oxford OX1 3PR, UK

$\ddagger$ Geological Institute Sonneggstrasse, Zürich, Switzerland

$\S$ United Institute of Geology, Geophysics and Mineralogy, Siberian Branch, Academy of Science, Novosibirsk, Russia

II Institute of Geology, Academy of Sciences of the MPR, Ulaan Baatar, Mongolia

(Accepted 8 February 1996)

\begin{abstract}
Diamictites, many of glacial origin, are globally distributed in the Neoproterozoic. Recently, two relatively thin diamictites in the Maikhan Uul Member at the base of the Neoproterozoic Tsagaan Oloom Formation from the Zavkhan Basin of western Mongolia have been identified as being of glacial origin. The Mongolian diamictites form a series of backstepping units within the transgressive systems tract of two major depositional sequences associated with sea-level changes. In each case the diamictites of the transgressive systems tract are abruptly overlain by deeper water, upward shoaling highstand systems tracts consisting of thinly bedded sandstones and shales in sequence 1 and thinly bedded, dark carbonates in sequence 3 . The fact that the sequences conform closely to depositional models established at other localities suggests that all are related to major ice ages and that the depositional sequences they have generated provide a valuable tool for global correlation in this part of the stratigraphic column. Available stratigraphic and isotope geochemical information presented by Brasier $\mathrm{et}$ al. (1996, this issue) suggests that both diamictites are likely to be of Sturtian age. A riftogenic setting and Sturtian age for the diamictites provide a link with eastern Australia and western America. It is possible, therefore, that these diamictites formed during the breakup of a supercontinental assembly including Siberia, Australia and Laurentia c. $750-725 \mathrm{Ma} \mathrm{BP}$.
\end{abstract}

\section{Introduction}

Neoproterozoic diamictites of glacial origin have been recognized on all continents (Chumakov, 1981; Hambrey \& Harland, 1985; Stump et al. 1988; Eyles, 1993). Their widespread distribution suggests the development of ice sheets over large areas of the planet during Neoproterozoic time. The recognition of such major climatic events is in itself significant. Perhaps of greater importance, however, is the fact that these events appear to be synchronous and may thus be of considerable value in correlation.

Neoproterozoic glacial rocks are widespread in Asia and on the Russian platform but were not known in western Mongolia until recently, in spite of the fact that sedimentary rocks of that age are present at several locations. Gibsher \& Khomentovsky (1990) have now identified two diamictites at the base of the Neoproterozoic Tsagaan Oloom Formation in the Zavkhan Basin (Fig. 1; in strata here placed in the Maikhan Uul Member) as a result of the work of the Joint Russian-Mongolian Scientific Research Geological and Palaeontological Expeditions. In 1993, the area was again visited by an international expedition as part of IGCP Project 303 which concluded that the diamictites were glacial in origin. The aim of this paper is to describe the diamictites, interpret their environment of deposition and place them in a sequence context as an aid to correlation. A valuable tool towards correlation is chemostratigraphy. Strontium and carbon isotope studies have been carried out on carbonate from the overlying sedimentary succession by Brasier $e$ t al. (1996, this issue). This helps not only in correlating such Neoproterozoic glacial associations with each other (where of course there is only minor palaeontological assistance) but also in detailing the possible relationships between late Precambrian glaciation, orogenic activity and ocean chemistry.

\section{Geological setting}

The Zavkhan Basin lies towards the western end of the Republic of Mongolia close to the city of Altay in GoviAltay Aimag (Fig. 1). This basin forms a structurally defined zone of Neoproterozoic and early Palaeozoic sedimentary rocks (Dorjnamjaa, 1989, 1991; Dorjnamjaa et al. 1993; Khomentovsky \& Gibsher, 1996, this issue). Exposures of earlier Proterozoic basement occur to the west, north and east of the zone. Several smaller basement blocks are also exposed within the basin. The basement complex consists of a lower gneissic group and an upper group consisting of marbles, 'calciphyres', amphibolites and quartzites which have been dated at 1.6 $\mathrm{Ga}$ (Dorjnamjaa \& Bat-Ireedui, 1991).

The sedimentary succession preserved within the 


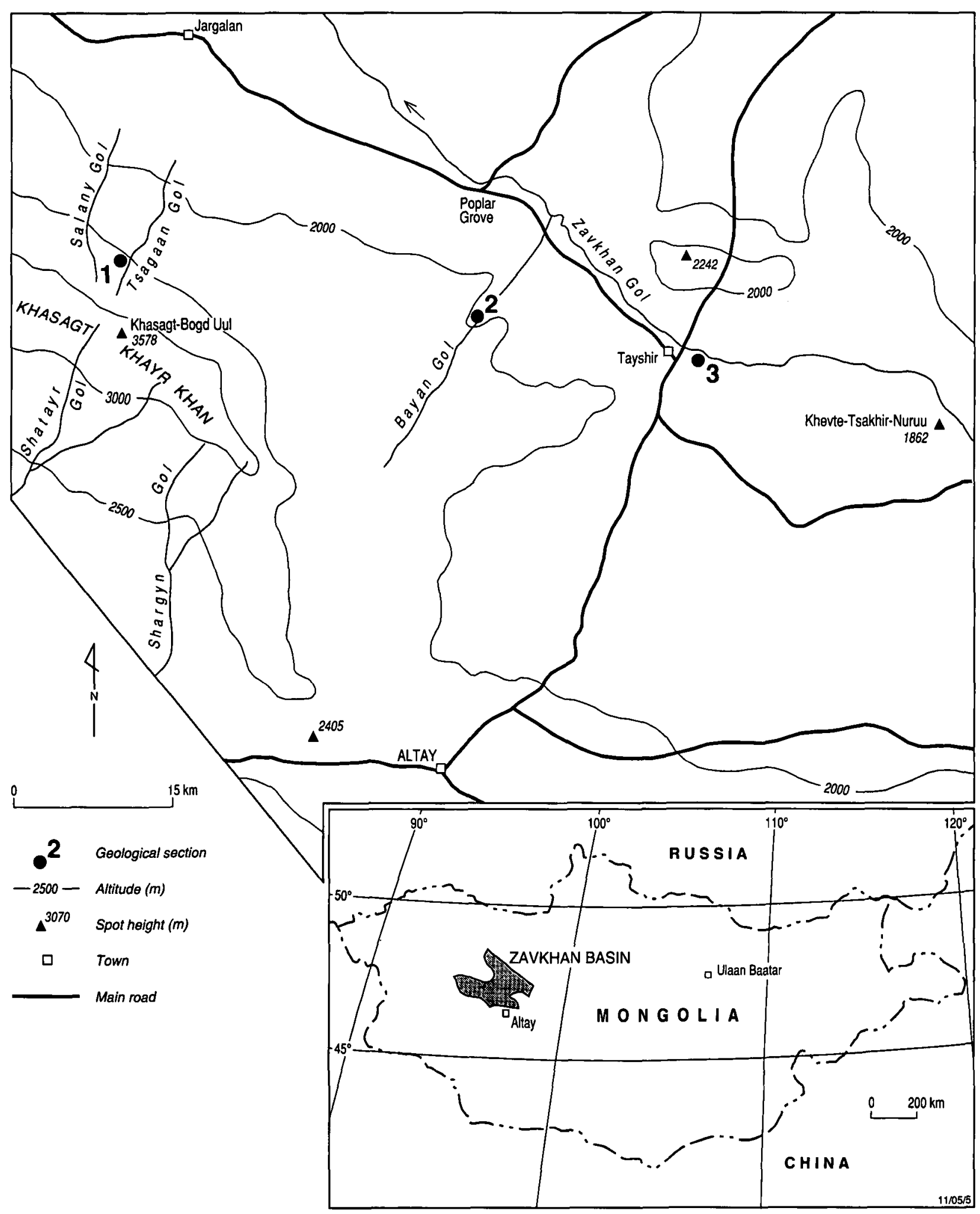

Figure 1. Locality map for the Zavkhan Basin and the Govi-Altay area of southwestern Mongolia showing the location of the three sections examined in detail: (1) the Tsagaan Gol section at the foot of the Khasagt-Khayr Khan Range, (2) the Bayan Gol section and (3) the Tayshir section on the Zavkhan Gol.

Zavkhan Basin appears to have been deposited in a large basin that evolved on sialic continental crust following fragmentation of the Baydrik-Tarbagatay microcontinent during the Baykalian (that is, Cryogenian, 850-650 Ma: Khomentovsky \& Gibsher, 1996, this issue). New strontium and carbon isotopic data (Brasier et al. 1996, this issue) suggest that this sedimentation began in the Cryogenian, c. 750-700 Ma BP. Subsidence rates appear to have been relatively slow during early stages of the basin evolution when the diamictites of the 
Tsagaan Oloom Formation were deposited but increased through time.

\section{Neoproterozoic and Cambrian stratigraphy}

Neoproterozoic and Cambrian sedimentary rock units exposed in the Zavkhan Basin have been divided into five formations, although only the lower three formations, the Dzabkhan, Tsagaan Oloom and Bayan Gol formations are relevant to this study (Fig. 2). The oldest unit, the Dzabkhan Formation, which rests unconformably on the basement, is relatively restricted in area. Fragments of basement rocks, including gneisses and granites, are incorporated into a basal conglomerate. The formation consists largely of silicic to intermediate volcanic rocks and associated ashes although, towards the top, arkosic and quartzose sandstones appear. The unit reaches approximately $2500 \mathrm{~m}$ in thickness and has been dated radiometrically at 732 to $777 \mathrm{Ma}$ (Dorjnamjaa et al. 1993). The Tsagaan Oloom Formation, which contains the diamictites at its base, rests unconformably upon the Dzabkhan Formation. The Tsagaan Oloom Formation, which is 1000 to $1500 \mathrm{~m}$ thick, consists of diamictites and other clastic units at its base but is dominated higher in the succession by platform carbonate units. The Bayan Gol Formation, which is at least $900 \mathrm{~m}$ thick, appears to be conformable on the Tsagaan Oloom Formation. The formation is largely clastic although siliciclastic-carbonate cycles are dominant in the lower part of the section (Dorjnamjaa et al. 1993).

The Tsagaan Oloom and Bayan Gol formations are very similar in depositional style. Both consist of a series of regular shoaling cycles. The cycles begin with deeperwater, dark, flaggy limestones or silty sandstones which grade upward to shallower water facies associations, including peritidal carbonates. There are a total of at least 12 cycles ( 13 if sequences 4 and $4 a$ are separate entities) in the Tsagaan Gol section, each representing a single unconformity-bounded depositional sequence (Fig. 2) (see Lindsay et al. 1996, this issue). The diamictites are to be found in sequences 1 and 3 in the siliciclastic Maikhan Uul Member at the base of the Tsagaan Oloom Formation (lower member of Khomentovsky \& Gibsher, 1996, this issue).

The Tsagaan Oloom Formation was deposited early in the development of the Zavkhan Basin when subsidence rates were low, resulting in depositional sequences that are widespread and geometrically condensed compared with passive margin settings, but very similar to those encountered in the slowly subsiding central Australian intracratonic settings (Lindsay, 1987, 1993; Kennard \& Lindsay, 1991; Lindsay, Kennard \& Southgate, 1993). In the central Australian intracratonic settings Cambrian sequences average $c$. 1-5 Ma in duration (Kennard \& Lindsay, 1991; Lindsay, Kennard \& Southgate, 1993). The chemostratigraphic data of Brasier et al. (1996, this issue) would suggest, however, an average span of anything up to 50 Ma duration for each Neoproterozoic sequence.

\section{The Maikhan Uul Member}

The Maikhan Uul Member (Beds 9-15, Fig. 2) at the base of the Tsagaan Oloom Formation includes two complete siliciclastic depositional sequences and the transgressive systems tract of a third sequence (sequences 1-3, Fig. 2). The highstand systems tract of the third sequence consists of carbonates (Bed 16, Fig. 2) which are included within the overlying member. Gibsher \& Khomentovsky (1990) described two diamictites (one in sequence 1 and the second in sequence 3 ) from this part of the Tsagaan Oloom Formation, in Tsagaan Gol valley below the Khasagt-Khayr Khan Range (Fig. 1, locality 1 and Fig. 3) $50 \mathrm{~km}$ west of Tayshir. The lower of the two diamictites is also exposed at Bayan Gol $15 \mathrm{~km}$ further east (locality 2, Fig. 1). At Bayan Gol, however, exposures are poor and the upper diamictite is not visible, either because of the soil cover, or because of removal by an unmapped thrust fault. A third section was visited near Tayshir on Zavkhan Gol $10 \mathrm{~km}$ east of locality 2 (Fig. 1). At this locality both diamictites are replaced by a 4-m-thick conglomeratic unit. The conglomerate is very poorly sorted and consists largely of locally derived, very angular granules and pebbles which suggests that it may be supraglacial (Brodzikowski \& van Loon, 1987) in origin and proximal to the basin margin. The conglomerate is overlain by black, thinly bedded, flaggy limestone which is probably equivalent to the basal unit of the Tsagaan Oloom Formation that overlies the upper diamictite in the Tsagaan Gol section. The following descriptions are consequently based on the relatively complete exposures at Tsagaan Gol (Fig. 1, locality 1).

\section{4.a. Sequence 1 (lower diamictite)}

The first sequence consists of two major depositional units, a 50-m-thick diamictite unit (Fig. 4) at the base and a 60-m-thick unit of alternating mudstones and thinly bedded sandstones at the top. The two units are interpreted to form the transgressive systems tract and the highstand systems tract of the sequence respectively (Fig. 2).

The lowermost sequence boundary of sequence 1 is a sharply defined erosion surface (Fig. 4). The diamictite sits directly upon the sequence boundary which shows considerable evidence of soft-sediment deformation due to sediment loading, suggesting only a limited hiatus. Overall the grey to grey-green diamictites are quite heterogeneous (Fig. 5) beginning at the base with crudely bedded units averaging one metre in thickness. Internally, the matrix has a distinctive fissility paralleling the bedding surfaces. The units contain a wide range of clast types and sizes which vary from highly angular to well rounded. Many of the clasts are volcanic rocks derived locally from the underlying Dzabkhan Formation, but there are also clasts of granite, limestone, quartz and quartzite derived from more distal sources. Maximum clast size typically ranges from 20 to $30 \mathrm{~cm}$. Calcareous concretions are relatively common in the crudely bedded 


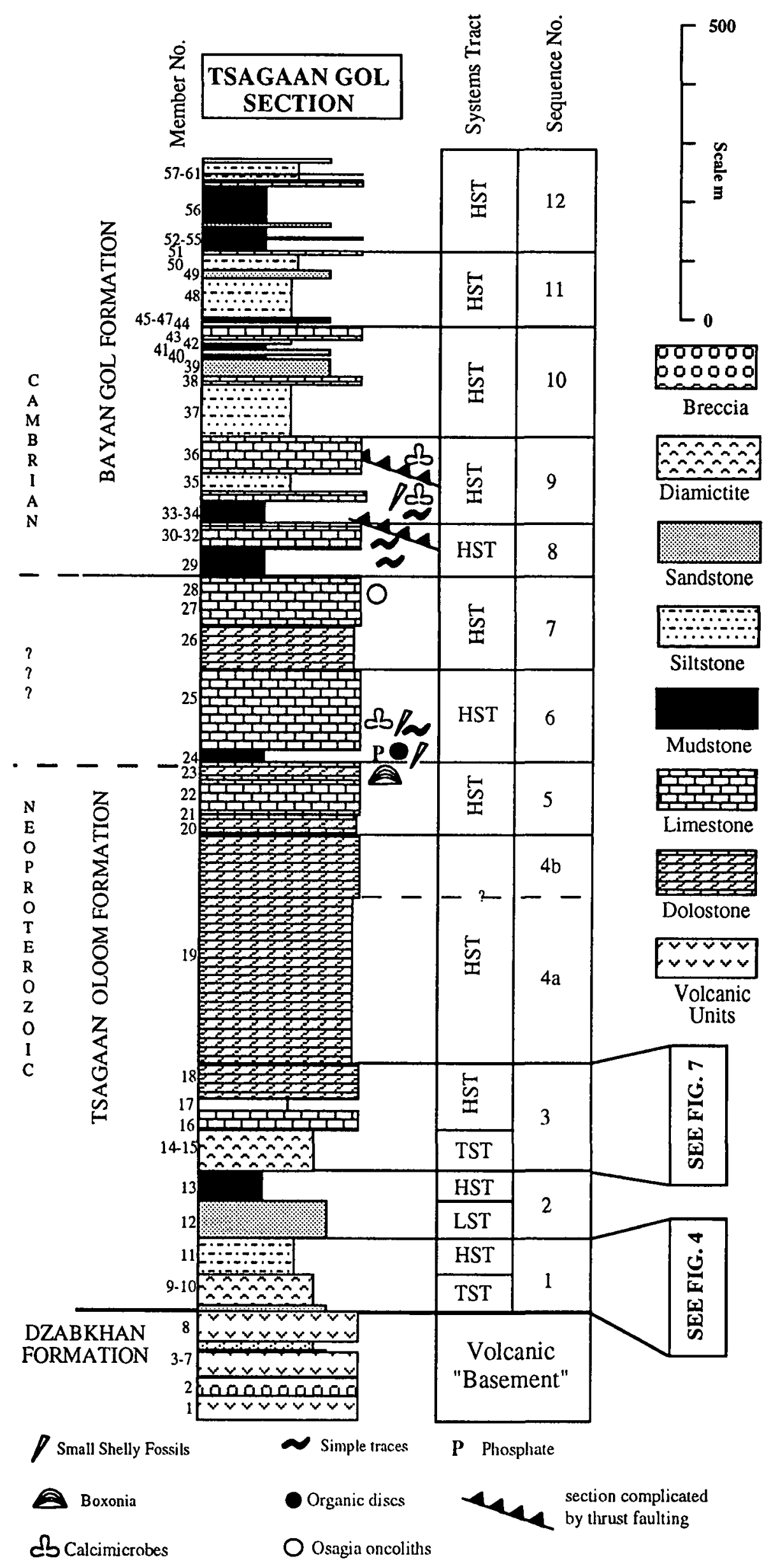

Figure 2. For legend see facing page. 


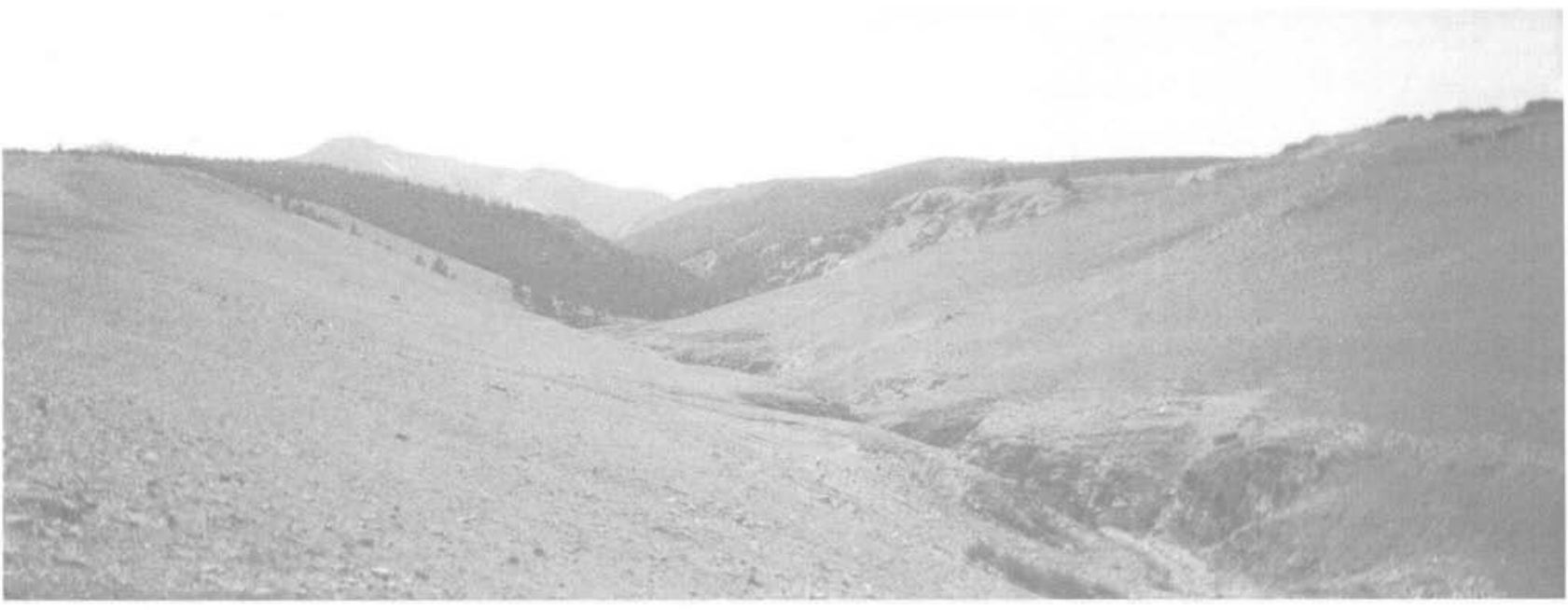

Figure 3. The view south along the Tsagaan Gol section. The two diamictite sequences begin in the foreground and extend upstream to the line of trees. The upper Tsagaan Oloom and the Bayan Gol formations are exposed at the base of Khasagt-Bogd Uul (3578 $\mathrm{m})$ the high peak on the Khasagt-Khayr Khan Range in the background.

basal unit. Similar massive diamictites occur for the first $10 \mathrm{~m}$ above the lower sequence boundary.

At $12 \mathrm{~m}$ above the lower sequence boundary, the section is interrupted by a $50-\mathrm{cm}$-thick, well-bedded, sandy diamictite unit. Above the bedded unit, the diamictite is once again relatively homogeneous, except for some calcareous concretions, to approximately $15 \mathrm{~m}$ above the lower sequence boundary.

At $15 \mathrm{~m}$ large clasts averaging $50 \mathrm{~cm}$ in diameter appears as a crudely organized single layer. The clasts are oriented and weakly striated, and at least one 'bullet shaped' clast (Boulton, 1978) was longitudinally striated. Above this clast layer, the character of the diamictite changes and it becomes more stratified and in general shows increasing evidence of water sorting in the form of pebbly and sandy layers. Evidence of water sorting is most abundant in the unit directly above the concentrated clast layer over a thickness of approximately seven metres. Maximum clast sizes vary from 15 to $30 \mathrm{~cm}$, although, in general, clast sizes decrease upwards as does the lithologic diversity of the clasts. The succession is interrupted periodically by calcareous concretionary zones, a feature common to many ancient glacial successions (Lindsay, 1970).

Sediments interpreted as a highstand systems tract rest abruptly upon the diamictites. The succession begins with olive-grey and grey-green shales with very rare thin sandstone interbeds. The shales are well-laminated and highly fissile. At a point $70 \mathrm{~m}$ above the base of the lower sequence boundary ( $20 \mathrm{~m}$ above the base of the highstand), thin sandstone units begin to appear more frequently in the succession and gradually increase in number and bed thickness until approximately $90 \mathrm{~m}$ above the base of the sequence, where sandstone becomes the dominant lithology (Fig. 6). In the 70 to 90 $\mathrm{m}$ interval, most sandstone beds are 2 to $5 \mathrm{~cm}$ thick, but a few reach a maximum of $45 \mathrm{~cm}$. The beds have sharp bases with scour and load-cast structures. They are well graded, with medium to coarse sands at their base passing upward to silt. Above $90 \mathrm{~m}$, the sandstones are grey to black in colour. The beds are thicker (typically $50 \mathrm{~cm}$ ) and contain a larger silt component than lower in the succession.

\section{4.b. Sequence 2}

The second sequence begins with a sandstone unit here identified as a lowstand systems tract (Fig. 2). This in turn is overlain by a highstand of relatively featureless shales. The lowstand of sequence 2 , which is approximately 60 $\mathrm{m}$ thick, consists of thickly bedded, grey-green, arkosic sandstones. At its base, the sandstone beds are massive and structureless units 1 to $1.5 \mathrm{~m}$ thick. Towards the top, the sandstone units thin to $10 \mathrm{~cm}$. All are structureless, although the thinner beds are more clearly stratified. It is likely that these upper, thinner beds form a transgressive unit, but the lack of structures makes any assessment difficult. The presumed highstand rests abruptly on a welldefined conformable surface at the top of the sandstones. It consists of $50 \mathrm{~m}$ of grey to black highly fissile shales. The shales are finely laminated but are otherwise devoid of sedimentary structures or sandstone interbeds.

Figure 2. Stratigraphic column for the Tsagaan Gol section on the north side of the Khasagt-Khayr Khan Range. Sequence stratigraphy and the associated systems tracts are outlined in the right hand column (HST - highstand systems tract, LST - lowstand systems tract, TST - transgressive systems tract). The stratigraphic column is adapted from Gibsher et al. (1991) while sequence stratigraphy is based on Lindsay et al. (1996, this issue). 


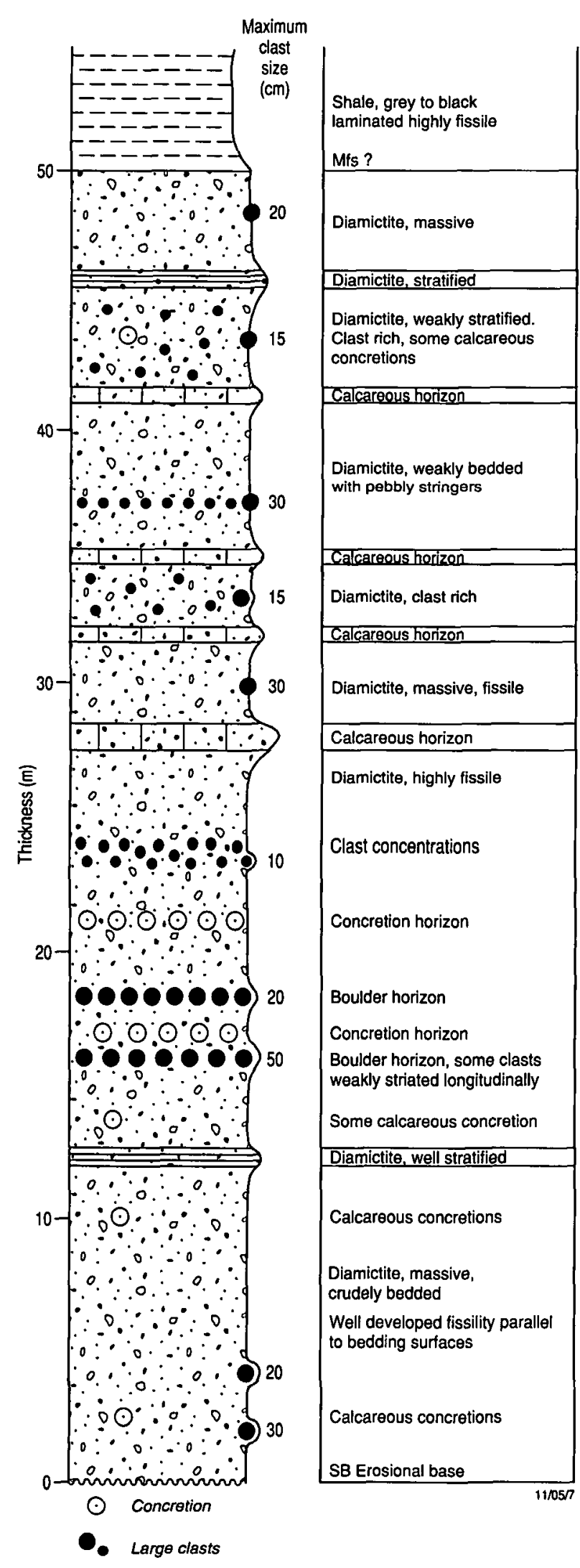

Figure 4. Stratigraphic column for the diamictites of sequence 1. Overall sorting within the diamictite unit was found to increase up-section whilst the diversity of clast lithology decreases. SB - sequence boundary, $\mathrm{mfs}$ - maximum flooding surface (downlap surface).

\section{4.c. Sequence 3 (upper diamictite)}

The diamictites of sequence 3 form a single unit (Beds 14 and 15, Fig. 2) $65 \mathrm{~m}$ thick that rests on a sharply-defined erosional surface with up to $70 \mathrm{~cm}$ relief locally (Fig. 7). The succession of diamictites is similar to that of sequence 1 . The basal diamictites, as in sequence 1 , are massive but show evidence of being lenticular. They have the same distinctive fissility roughly paralleling the bedding as for sequence 1 and contain a range of clast lithologies in a grey-green silty matrix. Clasts are generally andesitic lavas and tuffs as well as cherts, quartzites and, less frequently, coarsely crystalline granites. Clasts are up to $20 \mathrm{~cm}$ in diameter, the larger clasts generally being locally derived andesitic lavas and tuffs. Striated clasts are rare and the striations generally weakly defined. In contrast to the lower diamictite of sequence 1 calcareous concretions are only found in this basal unit of sequence 2 (Fig. 7).

Evidence of sorting begins much lower in the diamictites of sequence 3 than in sequence 1 with a wellbedded, calcareous, sand-rich unit appearing $3 \mathrm{~m}$ above the basal sequence boundary. The diamictite above this bedded sand-rich unit is much the same in colour as below but contains smaller clasts. At approximately 7 to 8 metres above the basal sequence boundary, spherical balls of sandy diamictite up to one metre in diameter occur within a more typical silty diamictite matrix.

In general, evidence of sorting within the diamictite unit in the form of stratified or bedded intervals increases upward, whereas maximum clast size decreases upward, except for the very top of the unit where locally derived quartzite clasts up to $40 \mathrm{~cm}$ in diameter appear. Clast composition also decreases in diversity upward such that the uppermost units mostly contain chert and quartzite clasts, the most resistant rock types. At $22 \mathrm{~m}$ above the basal sequence boundary, the first signs of soft-sediment deformation appear in the form of slump folds in discontinuously bedded units.

The highstand of sequence 3 differs from that of sequence 1 in that it consists almost entirely of limestones or dolostones which form a single shallowing upward succession about $105 \mathrm{~m}$ thick (Dorjnamjaa, 1989, 1991; Dorjnamjaa et al. 1993). The lower part of the succession consists of $30 \mathrm{~m}$ of dark grey or black, highly bituminous, thinly bedded and laminated flaggy limestones. They contain only trace dolomite. Approximately $20 \mathrm{~m}$ of the middle portion of the highstand is poorly exposed due to scree but appears to be the same as above. Above the poorly exposed interval, the succession consists of dark grey, massively bedded, fine-grained to micritic dolostones and patchily dolomitized limestones, changing upwards into dolostone. Towards the top, the dolostones contain oncolites (Gibsher et al. 1991). The upper contact (sequence boundary) of this unit is conformable but sharply defined, leading into a thick sequence of dark grey, bituminous calcareous dolostones and limestones of sabkha type in places. 


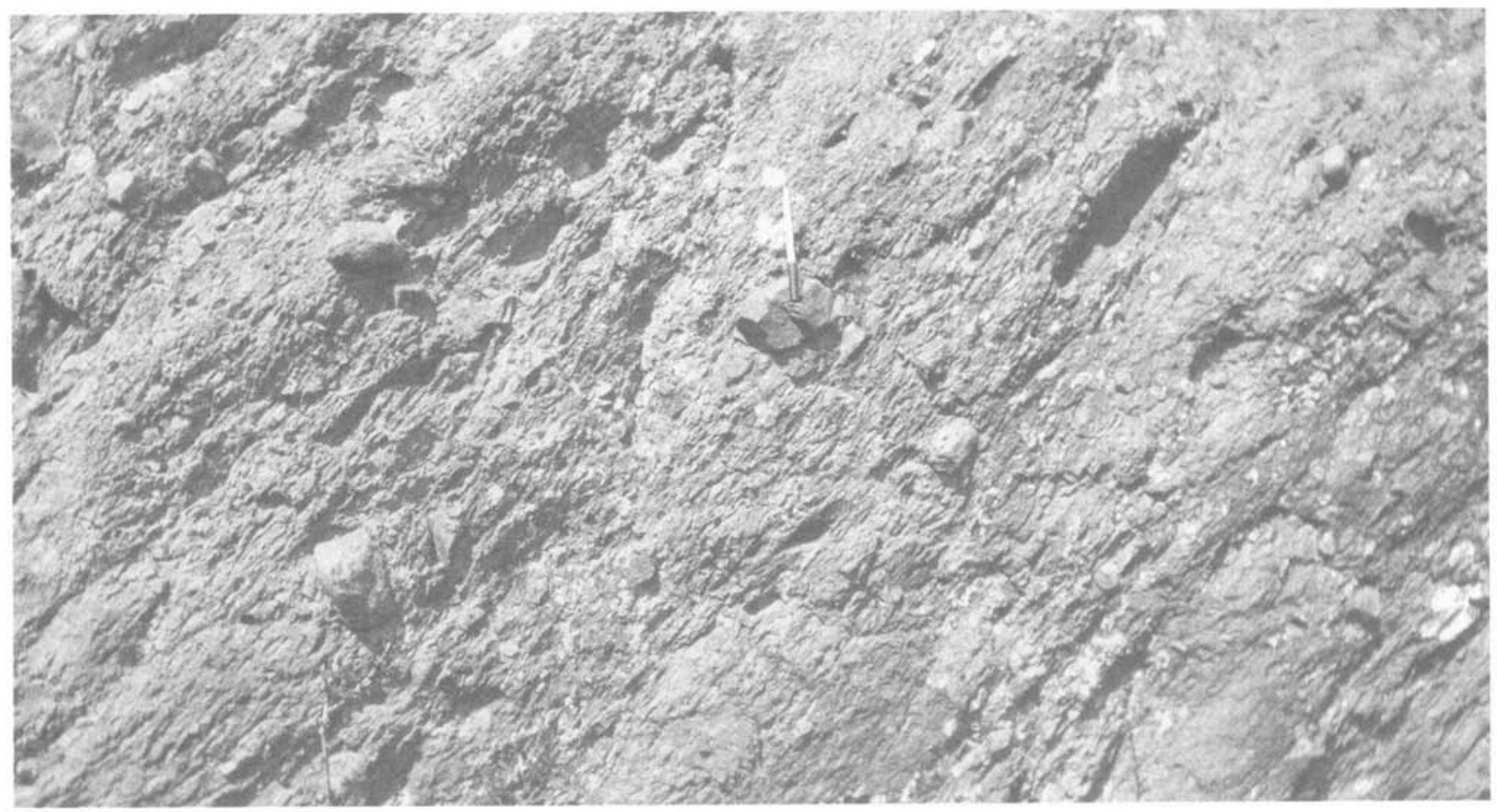

Figure 5. Diamictite from the middle of sequence 1 (Bed 10, Fig. 2) with clasts typically averaging $10 \mathrm{~cm}$. The diamictites exhibit a well-developed fissility. The pen to the right of centre gives the scale.

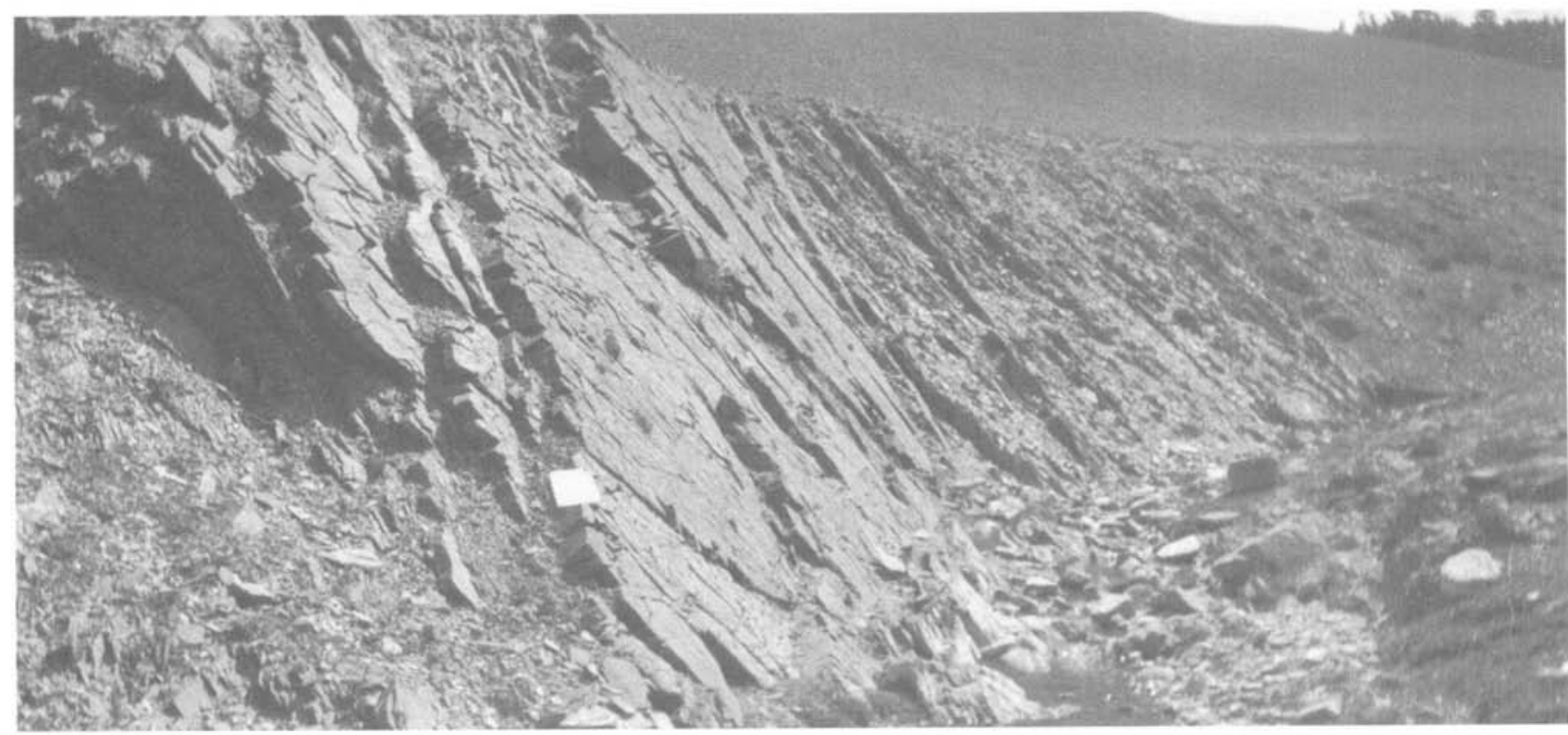

Figure 6. View of the middle and upper part of the highstand systems tract of the lower diamictite sequence (sequence 1, Bed 11, Fig. 2) showing thin-bedded sandstones and shales in the foreground. The sandstones all have sharp erosional bases with some current scouring and gradational tops. Most are well graded and show a full range of structures indicative of Bouma cycles. The sandstones appear to be storm-generated turbidites deposited basinward of a shoreface setting. The note book at the centre of the image is $20 \mathrm{~cm}$ square.

Nine samples were collected from this apparently shoaling-upward succession, (sequence 3) at about 5-10 $\mathrm{m}$ intervals for a geochemical study. Strontium and carbon isotope results discussed below indicate that this sequence was most likely deposited shortly after a worldwide pre-Varanger glaciation.

\section{Discussion}

\section{5.a. Depositional environment}

Unequivocal recognition of glacial sediments is at best difficult. By their nature, ice sheets develop on continental crust above sea-level and deposit much of their 


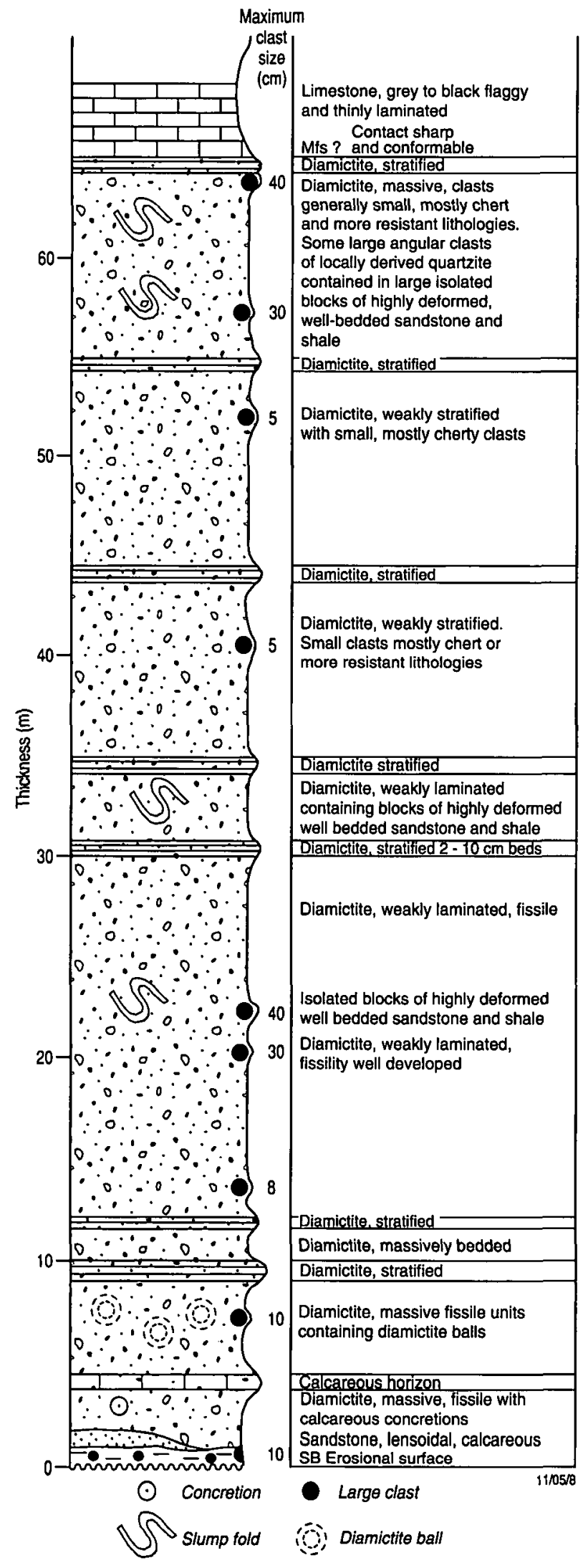

Figure 7. Stratigraphic column for the diamictites of sequence 2. As in the diamictites of sequence 1 sorting was found to increase upwards whereas clast size and compositional diversity decreased. SB - sequence boundary, mfs - maximum flooding surface (downlap surface). entrained sediment in supracratonic settings. Inevitably most supracratonic glacial sediments are eroded and resedimented by other mechanisms into adjacent basins and are not readily recognizable as being of glacial origin. Consequently, even though glaciations are major events in earth history, their sedimentary records are relatively poor and widely spaced in time.

However, at a planetary scale, ice sheets are of considerable significance in that they both reflect and modify global climate, depress the earth's crust over enormous areas and, perhaps most significantly, in terms of the present study, lock up, in solid form, a significant proportion of the earth's surface water, thus lowering sea level. Therefore, in situations where an ice sheet reaches the margins of an actively subsiding basin, it is highly likely to leave a distinctive sedimentary record. On the basis of work on Neoproterozoic successions in intracratonic settings in Australia, Lindsay (1989) argued that the sealevel cycle resulting from a major glaciation produces a depositional sequence with a predictable succession of facies associations, deposited as the ice advances and retreats.

Subsidence rate and basin architecture in Mongolia were broadly similar to the Australian settings so that the two diamictites described here from the Zavkhan Basin are broadly comparable to those in central Australia (cf. Lindsay, 1989). The lower part of the diamictite units of both the Mongolian depositional sequences (with their distinctive fissility and lenticular nature) are inferred, on this basis, to have been deposited within an ice-contact environment. At first, ice-contact sediments were deposited during the glacial maximum (that is, lowstand deposits or early stages of transgression). These were followed by evidence for a gradual retreat of the ice sheet and either a rise in sea-level or an increase in water depth. Although the facies associations in the two diamictites are thin by comparison with similar Neoproterozoic rocks of central Australia (Lindsay, 1989), it seems that the same general trends in facies are present.

The presence of the striated 'bullet-shaped' clast $15 \mathrm{~m}$ above the basal sequence boundary of sequence 1 and the concentrated layers of clasts suggest that, initially, ice was in contact with the diamictite as it was being deposited. 'Bullet shaped' clasts are generally regarded as a distinctive feature of debris carried in the basal traction zone of a glacier and common in lodgement tills (Boulton, 1978; Eyles, 1993). Lindsay (1989) found that clast concentrations are also distinctive for a glacial environment and are the result of selective lodgement of boulders as the ice at the ice/sediment interface approaches pressure melting point. Eyles (1994) has shown that some boulder pavements form in an intertidal setting. However, these features are armoured surface resulting from deflation whilst the boulder concentrations described here are in part clast supported with diamictite deposited between the boulders.

The transition to proglacial facies in sequence 3 is indicated by contained blocks of deformed stratified 
sediments in sequence 1 (Fig. 7). The appearance of the blocks of deformed stratified sediment provides evidence of mass movement, suggesting that sediment was rapidly deposited into a basinal setting and periodically failing downslope. Finally, the weakly stratified diamictites at the top of the succession show evidence of deposition from floating ice and thus increasing water depth. Similarly, the decline in the compositional diversity and size of clasts towards the top of the diamictites of both sequences (leaving only the smaller more resistant clasts) suggests that the ice or at least the clast source was gradually becoming more distal. That is, overall, the diamictites consist of a series of backstepping units, perhaps parasequences, deposited during transgression in a gradually deepening environment.

The possibility that some ice-contact diamictites at the base of the interval formed during the lowstand can not be overlooked. However, in the Mongolian setting, as in Australia, clear evidence of a lowstand systems tract is absent. If present, the lowstands are likely to be thin and restricted to the deepest parts of the basin. The advancing ice, upon reaching sea-level, would quickly disperse and deposit most of the sediments close to the basin margin, perhaps as gravity flow deposits. In the Amadeus Basin in central Australia, the lowermost sequence boundary beneath the diamictites is deeply erosional wherever it is encountered. This suggests that the drawing down of sea-level during glacial advance in the shallow, slowly subsiding basin may have resulted in an interval of erosion and non-deposition as grounded ice extended basinward much as proposed for the Plio-Pleistocene of the Antarctic Peninsula (Larter \& Barker, 1991). Indeed, the Amadeus Basin may never have been deep enough to develop a lowstand systems tract. The architecture of the Zavkhan Basin is poorly known but, again, clearly defined lowstand systems tracts were probably seldom deposited.

Carbonate-rich zones and concretions appear in the diamictites of both sequences 1 and 3 . Their occurrence appears to be typical of glacially derived diamictites although their full significance is not yet understood. The carbonates associated with modern glaciers have recently been shown to be authigenic and isotopically light in terms of both oxygen and carbon isotopes, rather than simply clastic in origin (Fairchild, Bradby \& Spiro, 1993). It seems likely that isotopic signatures of carbonates enclosed within diamictites may have potential as a tool in facies evaluation.

The two diamictites in sequences 1 and 3 appear to preserve, in large part, the transgressive systems tracts deposited from ice during glacial retreat and sea-level rise. It is likely, however, that at least a small thickness of the lodgement till at the base of each diamictite unit was deposited during the lowstand rather than the transgression. In both sequences, the facies associations within the transgressive systems tract generally conform to models of glaciomarine deposition proposed by Eyles, Eyles \& Miall (1985).

The diamictite units in sequences 1 and 3 are both overlain by thinly bedded, deeper water, marine sediments. In the case of the diamictites of sequence 1, the overlying unit is clastic whilst the upper diamictite in sequence 3 is overlain by carbonates. The overall facies association of the post-diamictite unit of sequence 1 suggests a gradual shallowing-upward marine setting. In its lower part, the sediments were deposited below storm-wave base. In the absence of dropstones and other evidence of glacial activity, the numerous thin sandstone beds are probably storm-generated turbidites, which carried coarser material into deeper water at infrequent intervals. This suggests a rapid deglaciation. Higher in the succession the sandstone units become thicker and more abundant, suggesting that the setting shallowed to a shoreface environment. Sequence 3 is not as well exposed in this section, but the lower carbonate units are more thinly bedded and darker in colour than the upper units. Oncolites towards the top of the unit are consistent with upward shoaling conditions.

In both cases, these more thinly bedded units appear with relative abruptness above the diamictites, indicating a rapid deepening of the water as sea-level rose following deglaciation. We emphasize that the transition to the highstand at the maximum flooding surface is abrupt, as in depositional sequences formed in other settings, rather than gradational as suggested by the model of Eyles, Eyles \& Miall (1985). This suggests that both diamictites are glacial in origin and that sea-level was rising rapidly in synchroniety with the deglaciations. Both post-diamictite successions (highstand systems tracts) show evidence that the depositional setting was shoaling upwards. The depositional space created by the sea-level rise was thus gradually filled as the highstand prograded across the diamictites of the transgressive systems tract following deglaciation.

Both post-diamictite units are thus highstand systems tracts formed in response to deglaciation. The fact that the diamictites conform so closely to the context of the sequence model leaves little doubt that they are synchronous with a major sea-level event. If they were simply the product of a local glacial event, the diamictites could be expected to occur at any point within the depositional sequence rather than at the base of the sequence. In such a circumstance the transition from ice-proximal to icedistal and finally nonglacial marine sedimentation could be expected to be gradational as suggested by the Eyles, Eyles \& Miall (1985) model. It is thus likely that the diamictites and their associated depositional sequences are the product of major sea-level cycles resulting from global ice ages. If this is the case, the glacial sequences offer important opportunities for global correlations.

The arkosic composition of the grey-green sandstones of sequence 2 suggests that they were derived by erosion from the diamictites associated with sequence 1 . In basinal settings, such as the Zavkhan Basin, lowstands are not always developed because of basin architecture and the low palaeoslope. The presence of the lowstand in sequence 2 suggests that the setting became more distal 
with time. Facies associations within the diamictites of sequence 3 similarly suggest that they were deposited in a more distal setting than diamictites in sequence 1 .

\section{5.b. Chemostratigraphy}

The sequence 3 transgression and highstand systems tract appears to relate to deglaciation. The subsequent deposition of at least $50 \mathrm{~m}$ of thinly bedded, commonly laminated, organic carbon- and sulphur-rich limestones represents an ideal opportunity for chemostratigraphy. The global nature of this transgression makes it reasonable to assume that any isotopic trends found in these, the first carbonates after the diamictite, could be of global significance. These limestones were analysed for strontium and carbon isotopes and results compared with similar published work from other Varangerian diamictite associations.

\section{5.c. Age and regional correlation}

Brasier et al. (1996, this issue) discuss the chemostratigraphy of carbonate rocks both below and above the Maikhan Uul diamictites and their results are briefly summarized below. Limestones at Kantayshir, which are supposedly coeval with the Dzabkhan Formation, have yielded a single ${ }^{87} \mathrm{Sr} /{ }^{\beta 6} \mathrm{Sr}$ ratio of 0.7057 , consistent with a Cryogenian age. Limestones above the upper Maikhan Uul diamictite reveal negative $\delta^{13} \mathrm{C}$ rising to extremely heavy values of $+11.4 \%$, and ${ }^{87} \mathrm{Sr} /{ }^{86} \mathrm{Sr}$ ratios of 0.7065 rising to 0.7073 . Taken together, these values, and the isotopic profiles obtained from sequence 4 , compare best with those thought to occur above the 'Sturtian'/'Rapitan' glaciation (cf. Derry, Kaufman \& Jacobsen, 1992; Smith et al. 1994). Brasier et al. (1996, this issue) also draw attention to evidence consistent with the later, Varangerian glaciation having taken place close to the base of sequence 5: widespread solution cavities and recrystallization are seen in the upper part of sequence 4; a sharp drop in $\delta^{13} \mathrm{C}$ values (to $+2.8 \%$ ) then takes place in the lower part of sequence 5 , while ${ }^{87} \mathrm{Sr} /{ }^{86} \mathrm{Sr}$ values fall slightly $(0.7072)$. A terminal Neoproterozoic age is suggested for sequences 5 and 6 , which have $\delta^{13} \mathrm{C}$ values that are mostly below $6 \%$ o and ${ }^{87} \mathrm{Sr} /{ }^{86} \mathrm{Sr}$ ratios that rise from 0.7072 to 0.7084 (cf. Kaufman, Jacobsen \& Knoll, 1993; Kaufman \& Knoll, 1995).

Biostratigraphic constraints on the age of the diamictite in the Zavkhan Basin are limited by the absence of a confirmed 'Ediacara fauna'. Trace fossils and small shelly fossils place the Precambrian-Cambrian boundary at some point between sequences 6 and 7 , some 500 to $600 \mathrm{~m}$ higher in the section. Closer definition is uncertain due to facies controls on fossil preservation (Lindsay et al. 1996, this issue). The volcanic rocks of the underlying Dzabkhan Formation have been dated radiometrically at 777-732 Ma (Dorjnamjaa et al. 1993), which is not inconsistent with the lower diamictite having a Riphean age (c. 700-750 Ma). More certain dating of the diamictites will require a more detailed isotope chronology, palaeontology and basin analysis.

The interpretation of Brasier et al. (1996, this issue) therefore suggests that the double diamictite of southwestern Mongolia is of Sturtian/Rapitan age, while the Varangerian glaciation is absent, represented only by a sequence boundary with evidence for emergence, and associated geochemical signatures. It is useful to compare this conclusion with evidence found in other parts of central Asia. This region consists of a complex of terranes of varying sizes, most of which appear to have been derived from the break up of the Proterozoic supercontinent towards the end of the Neoproterozoic (Ilyin, 1990). Hoffman (1991) in his reconstruction places Siberia and the smaller central Asian terranes at the northern edge of a supercontinent close to Australia but distant to Baltica. Diamictites of presumed glacial origin occur on all the smaller terranes (Chumakov, 1981, 1993). This apparent association implies that the central Asian glaciation was associated with an active margin prior to and during breakup. The glaciation may thus reflect relatively local but synchronous ice caps that formed in response to the uplift of parts of the active margin.

In contrast to the Zavkhan Basin, most of the central Asian sections contain only a single diamictite horizon, which have been regarded as regionally correlative and Vendian (Chumakov, 1981) or more recently as Riphean (Chumakov, 1993). The section with diamictites closest to the Zavkhan Basin which contains diamictites lies approximately $600 \mathrm{~km}$ to the north-northeast in the Darkhat-Khubsugul Rift (Ilyin, 1990). The section rests on crystalline basement and the depositional setting is very similar to that of the Zavkhan Basin. The earliest units overlying the basement are bimodal volcanic rocks which have been dated using $\mathrm{Rb} / \mathrm{Sr}$ ratios at $718 \mathrm{Ma}$ while comagmatic granites provide $\mathrm{K} / \mathrm{Ar}$ ages of $740 \mathrm{Ma}$. Above the volcanic rocks, the section consists mainly of arkosic cross-bedded sandstones which are then followed by diamictites, shales with dropstones and finally platform carbonates similar to the upper Tsagaan Oloom Formation. A lower diamictite has not been documented.

\section{Conclusion}

The diamictites of the Maikhan Uul Member of the Tsagaan Oloom Formation in the Zavkhan Basin of western Mongolia are contained within two depositional sequences and are separated by a further sequence. The facies associations within these sequences follow the same pattern found elsewhere in Neoproterozoic glacial successions and conform to a generalized model proposed by Lindsay (1989). The diamictites, in large part, appear to form transgressive systems tracts consisting of a succession of backstepping units deposited by the ice sheets as sea level rose during deglaciation. The diamictite succession includes ice contact units at the 
base, followed by evidence of gravity flow towards the top. The diamictites are then followed abruptly by deeper-water sediments which then shoal upwards. This suggests that they were deposited as a prograding highstand systems tract during the sea-level highstand that followed deglaciation. We infer that the two diamictites were deposited during a major ice age, and that the Mongolian diamictites are event markers with potential for global correlation.

Strontium and carbon isotopic evidence has provided a powerful tool in suggesting a Sturtian/Rapitan age for the two diamictites. It lends support to the hypothesis that this glaciation was more-or-less synchronous in Laurentia and Mongolia. It further increases the level of similarity between successions in southern Siberia (cf. Chumakov, 1993) and southwest Mongolia (cf. Khomentovsky \& Gibsher, 1996, this issue). An exciting possibility for future research is that these rift-related glaciogenic deposits along the present southern margin of the Siberian craton-Mongolia, may have formed part of a major rift system that has also preserved Sturtian glacial units in eastern Australia and Rapitan glacial units in western North America (Powell et al. 1993). Such a scenario would confirm that Siberia was indeed part of the major supercontinent 'Rodinia' that began to rift apart during Cryogenian time, at some time after c. 750-725 Ma BP.

Acknowledgements. We would like to thank Dr D. Dorjnamjaa who brought the members of the IGCP Project 303 team together in southwestern Mongolia. This paper is a contribution to IGCP Project 303. The study was funded in part by IGCP, The Australian Geological Survey Organisation and the Australian Department of Industry, Science and Technology; we are grateful for their support. GS is indebted to the ETH Zurich for its financial support, R. Steiger, F. Oberli \& M-T. Baer as well as P. Stille \& B. Kiefel of the CGS (CNRS) Strasbourg for their unstinting technical and scientific assistance. The manuscript was reviewed by Drs M. Deynoux, J. Miller, P. O'Brien and N. Christie-Blick and helpful suggestions were made by Prof. A. H. Knoll. The authors are grateful for their contributions.

\section{References}

Boulton, G. S. 1978. Boulder shapes and grain-size distribution of debris as indicators of transport paths through a glacier and till genesis. Sedimentology 25, 773-99.

Brasier, M. D., Shields, G., Kuleshov, V. N. \& Zhegallo, E. A. 1996. Integrated chemo- and biostratigraphic calibration of early animal evolution: Neoproterozoic-early Cambrian of southwest Mongolia. Geological Magazine 133, 445-85.

BrodZIKOWSKI, K. \& VAN LOON, A. J. 1987. A systematic classification of glacial and periglacial environments, facies and deposition. Earth-Science Reviews 24, 297-381.

Chumakov, N. M. 1981. Upper Proterozoic glaciogenic rocks and their stratigraphic significance. Precambrian Research 15, 373-95.

Chumakov, N. M. 1993. The middle Siberian glaciohorizon of the Riphean. Stratigraphyia. Geologiya Korrelyatsiya 1, 21-31 (in Russian).

Derry, L. A., Kaufman, A. J. \& Jacobsen, S. B. 1992. Sedimentary cycling and environmental change in the Late Proterozoic: Evidence from stable and radiogenic isotopes. Geochimica et Cosmochimica Acta 56, 1317-29.
DoRjnamjaA, D. 1989. The Precambrian stratigraphy of Mongolia. Novosibirsk, $32 \mathrm{pp}$. (in Russian).

DORJNAMJAA, D. 1991. Precambrian and Cambrian deposits in Mongolia and latest Precambrian phosphorites. IGCP Project 303: Precambrian and Cambrian event stratigraphy, Calgary, Alberta, Canada, $32 \mathrm{pp}$.

DorjnamjaA, D., Bat-Ireedui, Y. A., DashdavaA, Z. \& SOlEMAA, D. 1993. Guidebook for excursion Precambrian-Cambrian geology Khasagt-Khavrhan Ridge, Gobi-Altay Province, Mongolia. Geological Institute of the Mongolian Academy of Science, $36 \mathrm{pp}$.

DorjnamuaA, D. \& Bat-IReEdul, Y. A. 1991. The Precambrian of Mongolia. Ulaan Baatar, 182 pp. (in Russian).

EYLES, C. H. 1994. Intertidal boulder pavements in the northeastern gulf of Alaska and their geological significance. Sedimentary Geology 88, 161-73.

Eyles, C. H., Eyles, N. \& Miall, A. D. 1985. Models of glaciomarine sedimentation and their application to the interpretation of ancient glacial sequences. Palaeogeography, Palaeoclimatology, Palaeoecology 51, 15-84.

EYLES, N. 1993. Earth's glacial record and its tectonic setting. Earth-Science Reviews 35, 1-248.

FairChILD, I. J., Bradby, L. \& SpIRo, B. 1993. Carbonate diagenesis in ice. Geology 21, 901-4.

Gibsher, A. S. \& KHOMENTOvsKy, V. V. 1990. The Section of the Tsagaan Oloom and Bayan Gol Formations of the Vendian-Lower Cambrian in the Dzabkhan zone of Mongolia. In The Late Precambrian and Early Paleozoic of Siberia (eds V. V. Khomentovsky, A. S. Gibsher and G. A. Karlova), pp. 79-91. Novosibirsk: Institut Geologii i Geofiziki, Sibirskoe Otdelenie, Akademiya Nauk SSSR, 168 pp. (in Russian).

Gibsher, A. S., Bat-IreEdUi, Y. A., BalaKhonov, I. G. \& EFREMENKO, D. E. 1991. The Bayan Gol reference section of the Vendian-Lower Cambrian in central Mongolia (subdivision and correlation). In Late Precambrian and Early Palaeozoic of Siberia. Siberian Platform and its framework (ed. V.V. Khomentovsky), pp. 107-20. Novosibirsk: Ob'edinennyy Institut Geologii, Geofiziki i Mineralogii, Sibirskoe Otdelenie, Akademiya Nauk SSSR, 151 pp. (in Russian).

Hambrey, M. J. \& Harland, W. B. 1985. The Late Proterozoic glacial era. Palaeogeography, Palaeoclimatology, Palaeoecology 51, 255-72.

Hoffman, P. F. 1991. Did the breakout of Laurentia turn Gondwana inside-out? Science 252, 1409-12.

ILYIN, A. V. 1990. Proterozoic supercontinent, its latest Precambrian rifting, breakup, dispersal into smaller continents and subsidence of their margins: Evidence from Asia. Geology 18, 1231-4.

Kaufman, A. J., Jacobsen, S. B. \& Knoll, A. H. 1993. The Vendian record of $\mathrm{Sr}$ and $\mathrm{C}$ isotopic variations in seawater: Implications for tectonics and paleoclimate. Earth Planetary Science Letters 120, 409-30.

Kaufman, A. J. \& KNoll, A. H. 1995. Neoproterozoic variations in the C-isotopic composition of seawater: stratigraphic and biogeochemical implications. Precambrian Research 73, 27-49.

KenNard, J. M. \& LindSAY, J. F. 1991. Sequence stratigraphy of the latest Proterozoic-Cambrian Pertaoorrta Group, northern Amadeus Basin. Bureau of Mineral Resources, Australia, Bulletin 236, 171-94.

KHomentovsky, V. V. \& GibShER, A. S. 1996. The Neoproterozoic-lower Cambrian in northern Govi-Altay, western Mongolia: regional setting, lithostratigraphy and biostratigraphy. Geological Magazine 133, 371-90. 
LARTER, R. D. \& BARKER, P. F. 1991. Neogene interaction of tectonic and glacial processes at the Pacific margin of the Antarctic Peninsula. In Sedimentation, Tectonics and Eustacy, Sea-level Changes at the Continental Margin (ed. D. I. M. Macdonald), pp. 165-86. International Association of Sedimentologists Special Publication no. 12.

Lindsay, J. F. 1970. Depositional environment of Paleozoic glacial rocks in the central Transantarctic Mountains. Geological Society of American Bulletin 81, 1149-72.

LiNDSAY, J. F. 1987. Sequence stratigraphy and depositional controls in Late Proterozoic-Early Cambrian sediments of Amadeus Basin, central Australia. American Association of Petroleum Geologists Bulletin 71, 1387-1403.

LiNDSAY, J. F. 1989. Depositional controls on glacial facies associations in a basinal setting, Late Proterozoic, Amadeus Basin, central Australia. Palaeogeography, Palaeoclimatology, Palaeoecology 73, 205-32.

Lindsay, J. F. (ed.) 1993. Geological Atlas of the Amadeus Basin. Australian Geological Survey Organisation, Canberra, Australia, 25 plates.

Lindsay, J. F., Kennard, J. M. \& Southgate, P. N. 1993. Application of Sequence Stratigraphy in an Intracratonic
Setting, Amadeus Basin, central Australia. In Sequence stratigraphy and facies associations (eds $\mathrm{H}$. W. Posamentier, C. P. Summerhayes, B. U. Haq and G. P. Allen), pp. 605-31. IAS Special Publication no. 18.

Lindsay, J. F., Brasier, M. D., DorjnamjaA, D., Goldring, R., KRUSE, P. \& WOOD, R. A. 1996. Facies and sequence controls on the appearance of the Cambrian biota in southwestern Mongolia: implications for PrecambrianCambrian boundary. Geological Magazine 133, 417-28.

Powell, C. MCA., Li, Z. X., McElhinnY, M. W., Meert, J. G. \& PARK, J. K. 1993. Paleomagnetic constraints on timing of the Neoproterozoic breakup of Rodinia and the Cambrian formation of Gondwana. Geology 21, 880-92.

Smith, L. H., Kaufman, A. J., Knoll, A. H. \& LinK, P. K. 1994. Chemostratigraphy of predominantly siliciclastic Neoproterozoic succession: a case study of the Pocatello Formation and lower Brigham Group, Idaho, USA. Geological Magazine 131, 301-14.

Stump, E., Miller, J. M. G., Korsch, R. J. \& Edgerton, D. G. 1988. Diamictite from Nimrod Glacier area, Antarctica: Possible Proterozoic glaciation on the seventh continent. Geology 16, 225-8. 